\title{
Post-secondary apprenticeships for youth: Creating opportunities for high demand employment $^{1}$
}

\author{
Philip G. Wilson*, Susan G. Killam, Laura C. Stazio, Rebecca B. Ellis, Nicole M. Kiernan \\ and Amarachi N. Ukachu \\ Human Development Center, LSU Health Sciences Center, New Orleans, LA, USA
}

Revised/Accepted November 2016

\begin{abstract}
.
BACKGROUND: The Paid Apprenticeship and college for Youth with disabilities (PAY Check) program is a partnership between the states's University Center of Excellence in Developmental Disabilities (UCEDD), state Vocational Rehabilitation, Local Education Agencies (LEA), Delgado Community College (DCC) and University Medical Center-New Orleans (UMCNO). PAY Check uses a "braided" funding approach and builds on foundations established by an earlier post-secondary education (PSE) for youth with intellectual disabilities grant from the U.S. Department of Education. PAY Check includes a high school diploma option, PSE, paid apprenticeship components, and incorporates self-determination training throughout. The program serves students ages 18-21 years who receive special education services and are eligible for VR services. All components of PAY Check take place in integrated community settings (e.g., DCC campus, public transportation, paid apprenticeship sites) and provide opportunities for participants to acquire and practice pre-employment transition skills (Pre-ETS) as delineated in the Workforce Innovation and Opportunity Act (PL 113-803, 2016).

OBJECTIVE: This paper describes the unique transition program for youth with disabilities called PAY Check.

CONCLUSION: This article offers rationales for including its key components, discusses the programs development, provides an overview of the program, and concludes with recommendations for next steps.
\end{abstract}

Keywords: Apprenticeship, vocational rehabilitation, transition

\section{Introduction}

According to the Office of Disability Employment Policy (2016), only one-third (32.0\%) of working-age people with disabilities were employed on average in the 2010-2012 period, compared to nearly three-quarters $(72.7 \%)$ of people without disabilities. The U.S. Bureau of Labor Statistics estimated the 2014 youth (i.e., 16-19 years) unemployment rate for individuals with disabilities was approximately

\footnotetext{
${ }^{1}$ The authors express appreciation to John Johnson for support and comments on an earlier version of this manuscript.

*Address for correspondence: Philip G. Wilson, 411 South Prieur Street, New Orleans, LA 70112, USA. Tel.: +1 504556 7573; E-mail: pwilso2@1suhsc.edu.
}

$85-90 \%$ and the unemployment rate for non-disabled youth was estimated to be approximately $65-75 \%$ in 2014 . The unemployment rate for youth with disabilities ages 20-24 years was estimated to be $65-75 \%$ and approximately $33-40 \%$ for non-disabled youth ages 20-24 (U.S. Department of Labor, 2016). The appalling employment rate among individuals with disabilities continues to exist despite decades of research and practice demonstrating strategies to support the employment of individuals with disabilities (Cornell University, 2012).

A recent "perfect storm" of legislative, legal and policy advances may provide opportunities to increase participation in the workforce and career options for youth with disabilities. While some of 
these facilitators of change may not impact older individuals with disabilities directly, the impact on youth with disabilities should be significant. A brief review of key policy and legislative advances follows.

Research suggests that PSE has been shown to improve lifetime wage earnings and career advancement (Rabren, Eaves, Dunn, \& Darch, 2013). Including high school diploma options, PSE, paid apprenticeships, and self-determination training and practice opportunities provides a foundation for lifelong learning and career development. In the U.S. career exploration and development is generally associated with PSE. However, until recently individuals with disabilities have had limited opportunities to participate in PSE (Raue \& Lewis, 2011). Recent changes in the Higher Education Act (Higher Education Opportunity Act (2008). Pub. L. No. 110-315. 122 STAT. 3078 (2008) address these discriminatory barriers. Additionally, the U.S. Department of Education has invested in programs to establish effective models for youth with intellectual and other disabilities to participate in PSE; most notably the Transition and Postsecondary Programs for Students with Intellectual Disabilities (TPSID) initiative (United States department of Education, 2015). As a result, the number and quality of programs designed to support youth with disabilities to complete PSE programs that provide opportunities for participants to achieve employment outcomes and career goals has proliferated (University of Massachusetts Boston, 2016).

The Workforce Investment and Opportunities Act (WIOA) is another watershed piece of legislation (Department of Labor, 2016). The promulgated rules of WIOA encourage state VR and schools to develop and collaboratively implement programs and services to support the participation of youth with disabilities in the workforce. WIOA offers new opportunities to prepare the workforce and expand opportunities for workers and employers by including several key improvements to Federal training programs (e.g., stronger employer engagement, work-based learning approaches like apprenticeship, accountability for employment outcomes, etc.). The final WIOA regulations align with the Medicaid Home and Community Based Services (HCBS) "settings rule" (CMS, 2014). The settings rule limits HCBS waiver funds to services that support individuals with qualifying disabilities to live, work and participate fully in the community.

Policy-makers, service providers, and advocates have seized upon the triangulation of these and other important legislative, legal and policy developments (e.g., Americans with Disabilities Act, Olmstead decision, Medicaid settings rule) to establish the primacy of employment services and supports for people attempting to truly participate in all aspects of the community. The next section provides rationales for the inclusion of four key features of PAY Check.

\section{Rationale for key features of PAY Check}

PAY Check includes four key features including: (a) work-based high school diplomas, (b) postsecondary education, (c) paid apprenticeships, and (d) self-determination training. PAY Check is a comprehensive secondary transition program that uses a fully inclusive approach entirely based in natural community settings (Hart, Grigal, Sax, Matinez, \& Will, 2006). These components have been developed and primarily used in isolation in the past with mixed results. To the best of our knowledge, PAY Check is the first transition program for youth with disabilities that formally incorporates all four features.

\subsection{Work-based high school diplomas}

Research suggests that students who obtain high school diplomas achieve increased earnings and higher job satisfaction over their lifetimes. According to the U.S. Census Bureau (2012), on average high school dropouts earn $\$ 10,386$ less annually than high school graduates. Work-based diploma options for students, including students with disabilities, are common in the U.S. However, despite the availability of such diploma options in many states over the past several decades, unemployment/underemployment remain extremely high for young adults with disabilities. This observation suggests that possessing a high school diploma by itself is not sufficient to ensure employment outcomes for youth with disabilities (Smith, Grigal, \& Sullivan-Sulewski, 2012).

\subsection{Post-secondary education (PSE)}

The U.S. Department of Education has focused increased attention and resources on establishing PSE as a strategy to improve transition of youth with disabilities from school to community participation outcomes, especially employment and careers. The Georgetown University Center on Education and the Workforce projected a shortage of 3 million workers in the U.S. with technical training credentials due in part to the increasing share of jobs that require some 
form of PSE. In 1973, just $28 \%$ of U.S. jobs required PSE. By 2020, 65\% of jobs are expected to require PSE and only $36 \%$ of jobs are expected to be open to high school graduates without PSE (Jason Amos, 2013).

Research suggests that youth with disabilities who complete PSE programs may be more successful at obtaining community employment (Grigal, 2008; Grigal, Hart \& Paiewonsky, 2010-16; Hughson et al., Hughson, Moodie, \& Uditsky, 2006; Zaft, Hart \& Zimbrich, 2004-18; Grigal, Dwyre, 2010-19; Smith et al., 2012). While this approach has yielded some promising results, completing a course of studies at an institution of higher education (IHE) does not always guarantee employment and/or a career pathway for young people with disabilities (Smith et al., 2012).

\subsection{Paid apprenticeships}

Apprenticeships are a popular strategy to facilitate employment and career options for youth, albeit primarily for non-disabled youth, in some European countries. Apprenticeships provide pay to participants while they learn a set of skills through on-the-job training. Apprenticeship programs were first developed in Germany and differ from the internship model more commonly practiced in the U.S. and Canada. Internships provide a person with a general overview of a position for a short duration. Apprenticeships provide basic experience in a job or career path for job seekers who are still determining options. An apprenticeship provides an individual with more in-depth experience in a particular vocation or field. Apprenticeships nearly always include a combination of classroom and hands-on experience and generally include a training wage (REF-19).

There is a dearth of literature on the effectiveness of apprenticeships for youth with disabilities. However, we opted to include apprenticeships in the design of PAY Check due to positive outcomes achieved by youth without disabilities who complete apprenticeships (e.g., reduced unemployment among youth, improved transition from school to career, strengthen a young worker's identity and agency) and the potential to be effective for youth with disabilities as well (Delgado Community College Postsecondary Education for All Collaborative [PEAC] 2012).

\subsection{Self-determination training and practice}

Research has demonstrated that while youth and adults with disabilities have the capacity to be self- determined, they are generally less self-determined than their peers without disabilities (Stancliffe, Abery \& Smith, 2000; Wehmeyer, Kelchner \& Richards, 1996). When provided self-determination instruction people with disabilities are more self-determined (Wehmeyer, Palmer, Lee et al., 2011) and have higher rates of successful postsecondary (Morningstar, Frey, Noonan et al., 2010) and employment outcomes including higher wages and increased likelihood of receiving benefits such as vacation, sick leave and health care (Wehmeyer \& Bolding, 1999; Wehmeyer \& Palmer, 2003; Wehmeyer \& Schwartz, 1997).

\section{Development of PAY Check}

PAY Check was initially conceptualized as a way to build on and overcome key shortcomings of a previous TPSID project, Post-secondary Education for All Collaborative (PEAC) (Wilson, \& Lowrey, 2008) implemented at the same Community College (i.e., Delgado Community College) in New Orleans, Louisiana. The PEAC project was successful in supporting youth with ID complete work-based programs of study. In addition, we found that PEAC participants generally demonstrated improved communication, interpersonal and problem solving skills which is consistent with benefits of PSE for youth with disabilities reported in the literature (Page \& Chadsey-Rusch, 1995; Miller, DiSandro, Harrington, \& Johnson, 2016; Smith, \& Lugas, 2010). The majority of PEAC students obtained employment within 6-months of completing the program with assistance from a Community Rehabilitation Profession (CRP). However, most worked less than full-time and few worked directly in fields that aligned with their work-based program of study area. Only two PEAC completers obtained a high school diploma. Table 1 describes key shortcomings of prior model and components included in PAY Check to overcome them.

\section{Funding}

A braided funding approach was used to support the PAY Check program. This approach was designed to overcome the lack of involvement, communication and support from key stakeholders (i.e., state VR, VR counselors, CRPs, educators, and parents/guardians). To do this, we devised a funding scheme that required all stakeholders to have "skin in the game". 
Table 1

Shortcomings of previous model and current model solution

\begin{tabular}{ll}
\hline Shortcomings of PEAC & How PAY Check address issues \\
\hline $\begin{array}{l}\text { Lack of involvement, communication and support from } \\
\text { state VR }\end{array}$ & Third Party Cooperative Agreement (Braided funding) \\
$\begin{array}{c}\text { CRPs did not provide more efficient and career-focused } \\
\text { job matches }\end{array}$ & $\begin{array}{l}\text { Paid apprenticeships } \\
\text { Ongoing involvement of VR counselors }\end{array}$ \\
$\begin{array}{c}\text { CRPs did not use information about PEAC completers' } \\
\text { interests, strengths and needs }\end{array}$ & $\begin{array}{l}\text { Administrative buy-in from state VR } \\
\text { Ongoing communication with CRPs }\end{array}$ \\
& Staff attend/provide info at CRP meetings \\
Lack of communication between CRPs and PEAC staff & Apprenticeships provide opportunities for ongoing involvement of VR \\
& counselors \\
PEAC completers began working in fields that did not & Paid apprenticeship (e.g., could change need for Supported Employment to \\
relate directly to the career interests & Direct Placement in jobs that matches PSE and Apprenticeship experiences \\
Lack of communication between CRPs and PEAC staff & Apprenticeships provide opportunities for ongoing involvement of VR \\
& counselors \\
Less than optimal parent and school involvement & Increased expectations/commitments during recruitment process \\
& Recruitment-time "open house" \\
& Ongoing (bi-weekly) call or meeting \\
& Portfolios \\
& End of semester celebrations \\
& Staff attending school meetings \\
\hline
\end{tabular}

Specifically, the lead agency for the program contributed non-federally supported personnel to the project in-kind. Partner Local Education Agencies (LEA) provided a negotiated cash payment per student selected to participate using state or local funds and paid students' tuition and transportation using IDEA funds. State VR covered costs related to books and supplies at the PSE and apprenticeship sites. Parents/guardians were asked to pay for smart phone and monthly service for their child. In hardship cases, state VR and/or the LEA covered the cost of smart phones and monthly phone service. Although smart phones are ubiquitous in modern life they can be considered to be assistive technology (AT). In the case of PAY Check participants smart phones are indeed necessary AT for navigating the community, learning tasks, communicating, and self-management.

The lead agency's in-kind contribution and LEA cash payments were accepted by the state VR agency to be used to provide "match" funds which, in turn, were used to draw down additional funding from the Rehabilitation Services Administration (RSA) in accordance with Louisiana's Federal Financial Participation in State Expenditure (FMAP) program, as established by the Social Security Administration. Currently, the FMAP for Louisiana is set at $78.2 \%$. This allowed the combined non-federal dollars contributed to state VR to be used to draw down additional funds at a rate of nearly $4: 1$. State VR used the additional funds obtained from RSA to contract back to the lead agency via a Third Party Coop- erative Agreement. This arrangement has distinct advantages over time-limited grant funding in that it establishes mechanisms to both sustain and grow the program.

\section{Description of PAY Check program}

Students and their families were recruited from our partner high schools and were enrolled in DCC using a "concurrent enrollment" approach. This arrangement allows students to take classes at the community college to meet requirements for an alternate path to earn a high school diploma, complete an industrybased training certificate and/or begin earning credit toward an Associate's degree. While in PAY Check, students receive training and opportunities to practice Pre-ETS as defined in WIOA. The apprenticeship component provides participants a certificate of completion and paid work experience completers can include in their resumes and may enhance their motivation to obtain employment and pursue career goals. Self-determination training and opportunities to practice self-determination are included throughout all components of the program.

\section{Curriculum and sequence}

PAY Check is designed to be a 3-semester program. However, as with most services for students with disabilities, some participants will require a longer 
Table 2

Sample pay check weekly schedule - semester \#2

\begin{tabular}{|c|c|c|c|c|c|}
\hline Time & Monday & Tuesday & Wednesday & Thursday & Friday \\
\hline $8 \mathrm{am}$ & $\begin{array}{l}\text { Public bus to } \\
\text { DCC Check-In }\end{array}$ & & $\begin{array}{l}\text { Public bus to } \\
\text { DCC Check-In }\end{array}$ & & \\
\hline $\begin{array}{l}9 \mathrm{am} \\
10 \mathrm{am}\end{array}$ & $\begin{array}{l}\text { Customer } \\
\text { Service Class }\end{array}$ & & $\begin{array}{l}\text { Customer } \\
\text { Service Class }\end{array}$ & & \\
\hline $11 \mathrm{am}$ & $\begin{array}{l}\text { LUNCH } \\
\text { Take Streetcar to } \\
\text { UMC }\end{array}$ & $\begin{array}{c}\text { Arrive UMC } \\
\text { Check-In }\end{array}$ & $\begin{array}{l}\text { LUNCH } \\
\text { Take Streetcar to } \\
\text { UMC }\end{array}$ & $\begin{array}{c}\text { Arrive UMC } \\
\text { Check-In }\end{array}$ & $\begin{array}{c}\text { Arrive UMC } \\
\text { Check-In }\end{array}$ \\
\hline $\begin{array}{l}12 \mathrm{pm} \\
1 \mathrm{pm} \\
2 \mathrm{pm} \\
3 \mathrm{pm}\end{array}$ & $\begin{array}{l}\text { Apprenticeship at } \\
\text { University Medical } \\
\text { Center }\end{array}$ & $\begin{array}{l}\text { Apprenticeship at } \\
\text { University Medical } \\
\text { Center }\end{array}$ & $\begin{array}{l}\text { Apprenticeship at } \\
\text { University Medical } \\
\text { Center }\end{array}$ & $\begin{array}{l}\text { Apprenticeship at } \\
\text { University Medical } \\
\text { Center }\end{array}$ & $\begin{array}{l}\text { Apprenticeship at } \\
\text { University Medical } \\
\text { Center }\end{array}$ \\
\hline $4 \mathrm{pm}$ & $\begin{array}{l}\text { Check-Out } \\
\text { Public bus home } \\
\text { Text on arrival }\end{array}$ & $\begin{array}{l}\text { Check-Out } \\
\text { Public bus home } \\
\text { Text on arrival }\end{array}$ & $\begin{array}{l}\text { Check-Out } \\
\text { Public bus home } \\
\text { Text on arrival } \\
\end{array}$ & $\begin{array}{l}\text { Check-Out } \\
\text { Public bus home } \\
\text { Text on arrival } \\
\end{array}$ & $\begin{array}{l}\text { Check-Out } \\
\text { Public bus home, } \\
\text { Text on arrival } \\
\end{array}$ \\
\hline
\end{tabular}

time-frame (i.e., up to five-semesters) to complete all components of the program. The following section describes the content and sequence of the curriculum after recruitment, selection and orientation to PAY has occurred.

In the first semester participants take 2-3 classes selected from the DCC course catalog and receive instruction from Transition Coaches and opportunities to learn, practice and refine a number of Pre-ETS, with particular emphasis on independent use of smart phones, money and time management, as well as use of public transportation. PAY Check staff work closely with school personnel to ensure that students who wish to pursue high school diplomas through the program complete course work that supports them to graduate with a diploma at the end of the program.

At the end of the first semester, participants have a number of "job-shadowing" experiences at apprenticeship followed by completion of a person centered plan (PCP). Major outcomes of the PCP include identification of participants' preferred apprenticeship, resources available to the participant through personal networks of friends and family, as well as the supports and services he/she is likely to need to achieve college and employment-related goals.

During the second semester participants continue to take classes selected from the DCC course catalog to specifically inform/support their chosen apprenticeship and career path. Participants continue to learn, practice and refine Pre-ETS both on campus, at their apprenticeship site and in various other community locations. Participants begin working approximately 10 hours per week at their apprenticeship site after the first month of the semester with support from an on-site preceptor or supervisor and Transition Coaches, as needed.
Participants continue to take classes selected from the DCC catalog to specifically inform/support their apprenticeship and career path while refining and practicing Pre-ETS both on and off campus throughout the third semester. Participants increase the number of hours they work to approximately 15-30 hours per week based on individual abilities and needs after the first month of the semester.

At the end of the third, and if needed fourth, semester, the participant's progress toward completing high school diploma and DCC program of studies requirements, mastering Pre-ETS, and mastering critical components of the apprenticeship are reviewed with the participant, his/her family, LRS counselor, school personnel, supervisor/preceptor from the apprenticeship, and additional individuals the participant wishes to invite (e.g., friends, extended family members, service providers who may be involved in supporting the participant after completing PAY Check) to determine whether to continue in PAY Check program for a fourth (or fifth) semester or to exit and purse full-time competitive employment. The PCP is updated at this time, to guide continuation in the program or to specify the participant's career interests and employment and PSE goals in the short-term. This PCP serves as a document to the participant's transition from PAY Check to post-high school employment and career path.

Weekly schedules change across individual participants and semesters as the amount of time participants spend at their Apprenticeship increases. However, for the sake of illustration, Table 2 is presented to show a typical week for participants in the PAY Check program. This schedule is based on the second semester of participation when students are taking classes at DCC and working at their Apprenticeship site. 


\subsection{Self-determination training and practice}

As previously discussed, PAY Check participants must function in multiple "real world" community settings and activities. The program incorporates strategies to promote self-determination to promote, problem solving, independence and autonomy. For example, each day Transition Coaches meet participants and conduct a brief (i.e., >5 min) "check-in"/"check-out" process at the beginning/end of each day. Coaches and participants meet individually in a place determined mutually agreed upon (e.g., Student Life Center, bus stop, time clock at apprenticeship site). During Check-in, Transition Coaches ask participants to state a goal for the day or week related to skills/activities that are important in the settings/activities in which they are engaged and name actions they will perform to achieve their goal. At the end of the day, Coaches and participants meet again briefly. At this time, participants are asked to evaluate the extent to which they achieved their daily/weekly goal- and how well they performed the action steps they identified during Check-in. Checkout concludes after the participant states what, if anything, they will do differently to achieve their goal the next day. At both check-in and check-out, Coaches may suggest alternatives but final decisions are made by participants.

\section{Campus location}

Delgado Community College (DCC) is a public urban campus with enrollment of 16,500 students. Delgado offers 35 associate degree programs; 73 certificate, technical competency area, and technical diploma programs; and more than 100 non-credit courses (i.e., Adult Education) to meet the needs of every type of student, regardless of entry point, educational goal, or career aspiration. DCC is located adjacent to City Park in the mid-city neighborhood of New Orleans and is easily accessible by bus and street car lines. The campus is also within walking distance, or a short commute by street car and bus to many businesses, cultural and recreational venues. The setting provides immediate access to settings and activities that are ideal for teaching and practicing Pre-ETS due to its location within a vibrant urban neighborhood and accessible public transportation.

\section{Recruitment and selection}

Applicants included students between 18 and 21 years, with a qualifying disability and eligible for the VR program and Pre-ETS program as defined by Louisiana Rehabilitation Services (LRS). PAY Check staff and representatives of state VR reviewed the

Table 3

PAY Check student characteristics

\begin{tabular}{|c|c|c|c|c|c|c|c|}
\hline $\begin{array}{l}\text { Student } \\
\text { Initials }\end{array}$ & Gender & LEA & IDEA & $\begin{array}{l}\text { Exit Doc: } \\
\text { HS Diploma } \\
\text { or Non-Diploma } \\
\text { Certificate }\end{array}$ & $\begin{array}{l}\text { Transition Courses } \\
\text { of Study: Individual } \\
\text { Graduation Plan } \\
\text { (IGP) or Individual } \\
\text { Plan for Instruction } \\
\text { (IPI) }\end{array}$ & $\begin{array}{l}\text { Primary } \\
\text { Exceptionality }\end{array}$ & $\begin{array}{l}\text { Disability Supports: } \\
\text { ET = Extended } \\
\text { Time-Tests/Tasks, D-F = Distraction } \\
\text { Free Setting, Reader, } \\
\text { Calc. = Calculator, } \\
\text { Scribe = Assistance with Notes, } \\
\text { No Scantron, LP = Enlarge Print, } \\
\text { RTQ = Rephrase Test Questions }\end{array}$ \\
\hline AW & M & Charter & IEP & Certificate & Ind. Grad. Plan & Autism & ET, D-F, Reader, Calc., RTQ \\
\hline DJ & M & Charter & IEP & Diploma & Ind. Grad. Plan & IDD - Mild & ET, Reader, Calc. \\
\hline DB & M & Public & IEP & Certificate & Ind. Grad. Plan & $\begin{array}{l}\text { Other Health } \\
\text { Impairments }\end{array}$ & ET, Reader, Calc., RTQ \\
\hline DS & $\mathrm{F}$ & Charter & IEP & Certificate & Ind. Grad. Plan & $\begin{array}{l}\text { Emotional } \\
\text { Disturbance }\end{array}$ & ET, Reader, Calc. \\
\hline GA & $\mathrm{F}$ & Public & IEP & Diploma & $\begin{array}{l}\text { Ind. Prescription } \\
\text { for Instruction }\end{array}$ & IDD - Mild & ET, Reader, Calc. RTQ \\
\hline KS & $\mathrm{F}$ & Public & N/A & Diploma & N/A & $\begin{array}{l}\text { Emotional } \\
\text { Disturbance }\end{array}$ & ET, Scribe, No Scantron \\
\hline SN & $\mathrm{F}$ & Charter & IEP & Diploma & $\begin{array}{l}\text { Ind. Prescription } \\
\text { for Instruction }\end{array}$ & IDD - Mild & ET, Reader, Calc., Scribe, RTQ \\
\hline TS & M & Public & IEP & Certificate & Ind. Grad. Plan & Specific LD & ET, D-F, Reader \\
\hline $\mathrm{TE}$ & $\mathrm{F}$ & Public & IEP & Diploma & Ind. Grad. Plan & Specific LD & ET, D-F, Reader, Calc. \\
\hline TM & M & Charter & IEP & Diploma & Ind. Grad. Plan & IDD - Mild & $\begin{array}{l}\text { ET, Reader, Calc., Scribe, } \\
\text { No Scantron, LP, RTQ }\end{array}$ \\
\hline $\mathrm{TL}$ & $\mathrm{F}$ & Charter & IEP & Diploma & Ind. Grad. Plan & IDD - Mild & $\begin{array}{l}\text { ET, Reader, Calc., Scribe, } \\
\text { No Scantron, LP, RTQ }\end{array}$ \\
\hline WJ & M & Public & IEP & Certificate & Ind. Grad. Plan & IDD - Mild & ET, Reader, Calc., RTQ \\
\hline
\end{tabular}


pool of applicants, rank ordered and selected an initial cohort of twelve youth who met all criteria.

Prior to the beginning of the first semester, individual participant Team meetings were held to create plans with action steps, responsible persons and timelines to ensure the participant is able to complete the program and earn a high school diploma. Participants who chose to opt out of this component were required to provide written documentation of the intention to waive this component and a brief explanation of why (e.g., some already have a plan in place to earn their diploma). Table 3 provides a description of characteristics of the 12 individuals in the first cohort of PAY Check participants.

\section{Next steps}

PAY Check is a multi-component secondary transition program for youth with disabilities that prepares them for employment and career paths of their choosing. The program primarily serves students from inner city schools in the Greater New Orleans area. PAY Check represents an example of the crossagency collaborative transition effort described in the rules promulgated in WIOA.

Next steps for PAY Check include expanding the number, type and location of apprenticeship offerings to ensure future participants are afforded a larger range of employment and career path options. To do this, the program is recruiting additional employers to serve as apprenticeship hosts. Similarly, the program needs to be expanded to LEAs in other communities and replicated at other IHE's both in state and out of state.

In order to more fully prepare participants to transition to adult lifestyles and full participation in the community as adults, the program should expand to address skills other than employment and career. This would likely best be accomplished through exploring full- or part-time residential experiences based at an IHE or other community residential settings.

Recently, the U.S. Department of Labor (DOL) has demonstrated renewed interest in establishing registered apprenticeships and pre-apprenticeships. Future program enhancements should involve establishing current and additional PAY Check apprenticeship offerings as official DOL apprenticeships. Doing so may make it easier to attract additional employers and replicate the program in different regions of the country. Finally, while PAY Check is primarily a model demonstration project, research on the components of the program could inform and guide efforts to improve, enhance and bring the project to scale.

\section{Acknowledgments}

The authors express appreciation to John Johnson for support and comments on an earlier version of this manuscript.

\section{Conflict of interest}

The authors have no conflict of interest to report.

\section{References}

Amos, J. (2013). FUTURE SHOCK: By 2020, 65\% of Jobs to Require Postsecondary Education, Only 36 Percent of Jobs Expected to Be Open to High School Graduates, Finds New Report. Straight A's Newsletter, 13(14), Alliance for Excellent Education, Washington, D.C.

Department of Labor (2016). Training and Employment Notice. Retrieved November 15, 2016 from http://wdr.doleta. gov/directives/attach/TEN/TEN 42-15-Change1 Acc.pdf

Cornell University (2012). Employer best practices supporting the hiring, retention, and promotion of people with disabilities: A bibliography. Retrieved November 6, 2016 from http://digitalcommons.ilr.cornell.edu/cgi/viewcontent.cgi? article $=1291 \&$ context $=$ edicollect

Grigal, M., Smith, F., \& Sullivan, J. (2012). www. thinkcollege.net. Retrieved November 6, 2016 from http:// www.thinkcollege.net/administrator/components/comresdb/ files/Insight15 D2.pdf

Hart, D., Grigal, M., Sax, C., Martinez, D., \& Will, M. (2006). Postsecondary Options for Students with Intellectual Disabilities. Research to Practice Brief \#46, Institute for Community Inclusion, University of Assachusetts, Boston.

Higher Education Opportunity Act (2008). Pub. L. No. 110315. 122 STAT. 3078 (2008). United States Department of Education.

Hughson, E. A., Moodie, S., \& Uditsky, B. (2006). The story of inclusive post-secondary education in Alberta, final research report 2004-2005. (Self-published) Retrieved November 6, 2016 from https://www.thinkcollege.net/ administrator/components/comresdb/files/TheStoryofInclusiv ePost-SecondaryEducationinAlberta.pdf

Medicaid Program, State Plan Home and CommunityBased Services, 5-Year Period for Waivers, Provider Payment Reassignment, and Home and CommunityBased Setting Requirements for Community First Choice and Home and Community-Based Services (HCBS) Waivers (2014). Retrieved November 4, 2016, from https://www.federalregister.gov/documents/2014/01/16/201400487/medicaid-program-state-plan-home-and-communitybased-services-5-year-period-for-waivers-provider 
Miller, K. D., DiSandro, R., Harrington, L., \& Johnson, J. S. (2016). Inclusive higher education is reaping benefits for individuals with intellectual disabilities: One program's story. Think College Insight Brief, Issue No. 29. Boston, MA: University of Massachusetts Boston, Institute for Community Inclusion.

Morningstar, M. E., Frey, B. B., Noonan, P. M., Ng, J., ClavennaDeane, B., Graves, P., Kellems, R., McCall, Z., Pearson, M., Wade, D. B., \& Williams-Diehm, K. (2010). A preliminary investigation of the relationship of transition preparation and self-determination for students with disabilities in postsecondary educational settings. Career Development for Exceptional Individuals, 33(2), 80-94.

Page, B., \& Chadsey-Rusch, J. (1995). The community college experience for students with and without disabilities: A viable transition outcome? Career Development of Exceptional Individuals, 18(2), 85-96.

Rabren, K., Eaves, R. C., Dunn, C., \& Darch, C. (2013). Students with learning disabilities' satisfaction, employment, and postsecondary education outcomes. Journal of Education and Learning, 2(2), 14-22.

Raue \& Lewis (2011). Students with disabilities at degree-granting postsecondary institutions (NCES 2011-018). U.S. Department of Education, National Center for Education Statistics. Washington, D.C.: U.S. Government Printing Office.

Smith, F. A., Grigal, M. \& Sulewski, J. (2012). The Impact of Postsecondary Education on Employment Outcomes for Transition-age Age Youth with and Without Disabilities: A Secondary Analysis of American Community Survey Data. Think College Insight Brief, Issue No. 15. Boston, MA: University of Massachusetts Boston, Institute for Community Inclusion.

Stancliffe, R. J., Abery, B. H., \& Smith, J. (2000). Personal control and the ecology of community living settings: Beyond living-unit size and type. American Journal on Mental Retardation, 105, 431-454. Retrieved November 6, 2016 from https://experts.umn.edu/en/publications/personalcontrol-and-the-ecology-of-community-living-settings-bey
Team, G. (2016). 6 Differences between an Internship and Apprenticeship. Retrieved November 6, 2016 from https://www.glassdoor.com/blog/6-differences-internshipapprenticeship/

U.S. Census Bureau (n.d.). Retrieved November 15, 2016, from http://www.route247.org/news/high-school-graduationfacts-ending-the-dropout-crisis/

U.S. Department of Labor (2016). doleta.gov. Retrieved November 6, 2016 from https://www.doleta.gov/Grants/pdf/FOA-ETA16-07.pdf

University of Massachusetts Boston (2016). Think College: College options for people with intellectual disabilities. Retrieved November 4, 2016 from http://www. thinkcollege.net/component/resdb/item/t-110/1137

Wehmeyer, M. L., Kelchner, K., \& Richards, S. (1996). Essential characteristics of self-determined behavior of individuals with mental retardation. American Journal on Mental Retardation, 100(6), 632-642.

Wehmeyer, M. L., Palmer, S. B., Lee, Y., Williams-Diehm, K., \& Shogren, K. (2010). A preliminary investigation of the relationship of transition preparation and self-determination for students with disabilities in postsecondary educational settings. Career Development for Exceptional Individuals, 33(2), 80-94.

Wehmeyer, M. L., Palmer, S. B., Lee, Y., Williams-Diehm, K., \& Shogren, K. (2011). A randomized trial evaluation of the effect of whose future is it anyway? On self-determination. Career Development for Exceptional Individuals, 34(1), 45-56.

Wehmeyer, M. L. \& Palmer, S. B. (2003). Adult outcomes for students with cognitive disabilities three-years after high school: The impact of self-determination. Education and Training in Developmental Disabilities, 38(2), 131-144.

Wehmeyer, M. L. \&. Schwartz, M. (1997). Self-determination and positive adult outcomes: A follow-up study of youth with mental retardation and learning disabilities. Exceptional Children, $63,245-255$. 